安全弁による低圧化システムの圧力制御対策（IV）

一 自動減圧弁を並列設置した場合 -

稲垣仁根 ${ }^{1} \cdot$ 高橋研二 $^{2} \cdot$ 多炭雅博 $^{3} \cdot$ 竹下伸一 ${ }^{3}$

\title{
Pressure Countermeasure Control on Pressure-reducing Pipeline System Using Safety Valve(IV)
}

-In the Case of Automatic Control Valves installed in Parallel-

\author{
Hitone Inagaki ${ }^{1}$, Kenji Takahashi $^{2}$, Masahiro Tasumi ${ }^{3}$ and Shinichi Takeshita ${ }^{3}$
}

\begin{abstract}
A field test was conducted on the stability of a pressure-reducing system combining a new type of automatic control valve in parallel with a conventional automatic control valve in a test pipeline in Ohno Mountain of Kagoshima Prefecture. The pressure control functions which include initiation of water flow and closing during transient conditions of increases and decreases in flow were investigated in a field experiment. The results were as follows:

(1) When the conventional and new type automatic control valves are employed in parallel, and a safety valve is not used, the characteristics of the conventional valve take precedence. So when the flow is stopped, pressure builds up in the up- and down-stream sides of the valves.

(2) It is possible to combine the conventional and new type automatic control valves in a series installation. But when they are installed in parallel as a main valve and a bypass valve, respectively, countermeasure comprising concurrent installation of a safety valve to control the secondary side pressure of the control valves is needed.

(3) The pressure control functions of conventional control valves are not as effective as the new type of control valve during stopped flow and very low-volume flows, so it is difficult to deal with changes in flow volume with an end valve. Furthermore, conventional control valves are slower in operation than the new type of control valve. Thus, if the conventional model is installed as the main valve in combination with the new model installed as the bypass valve, the system will no longer be dependent on the safety valve for control of secondary side pressure of the control valve. And with this, it will be possible to control the pressure in response to changes in flow rate.
\end{abstract}

Keywords: Automatic Control Valve; Pressure-reducing Pipeline; Installation in parallel; Safety Valve; Pressure Control

1 はじめに

パイプラインの低圧化システムは, 減圧弁により減圧弁 下流側の管路の設計圧力の削減を行い, 安価で耐圧強 度の低い塩化ビニル管の使用を可能にして, コストダウン を図ることを目的としている. 減圧弁を単独で設置した場 合の低圧化システムの概要を図1に示している.

著者らは, 鹿児島県の大野岳に設置した実験専用の低 圧化パイプラインシステムを用いて, 一台の減圧弁を設置 した場合の実験を行い, 減圧弁の圧力制御機能の検証を 行った(高橋ら，2009a). さらに, 減圧弁と安全弁を併用寸 ることにより, 減圧弁の2次側 (下流側) 圧力を安全弁の設 定圧力 $+10 \mathrm{~m}$ 程度の圧力に制御できることを確認している （高橋ら， 2009b). また, 著者らは, 低圧化システムをより 有効に活用寸るために, 二台の減圧弁を直列配置した場 合の実験を行い, 減圧弁と安全弁を併用することにより, 設計圧力の段階的な削減が可能であることを示している

1 宮崎大学農学部教授, Professor, Faculty of Agriculture, Miyazaki University, 1-1 Gakuen Kibanadai-nishi, Miyazaki 889-2192, Japan (Corresponding Author) E-mail:a03221u@cc.miyazaki-u.ac.jp

宮崎大学大学院農学工学総合研究科, Postgraduate Student, Interdisciplinary Graduate School of Agriculture and Engineering, Miyazaki University, 1-1 Gakuen Kibanadai-nishi, Miyazaki 889-2192, Japan

3 宮崎大学農学部准教授, Associate Professor, Faculty of Agriculture, Miyazaki University, 1-1 Gakuen Kibanadai-nishi, Miyazaki 889-2192, Japan
(高橋ら, 2010).

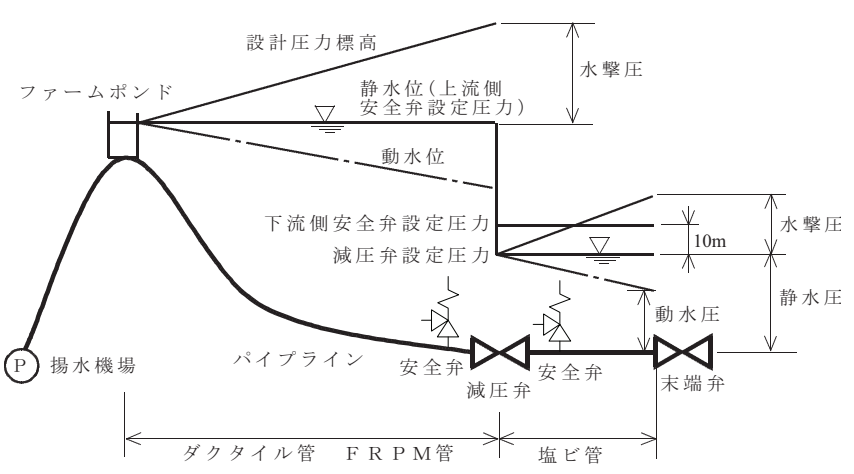

図 1: 低圧化システムの概要

一般的に, パイプラインにおいては流速を適正範囲に 収めるため, 設計流量の大きさに忘じてパイプラインのロ 径が設定される. 従って, 設計流量よりも小さい流量を通 水する時には, 減圧弁による減圧量が大きくなり, 減圧弁 の弁体ピストンが閉鎖直前の小さい開度で制御されるた め, 短い周期で開閉を繰り返す現象であるハンチングが 発生しやすくなる傾向にある. 低圧化システムを稼働する 際に, 通水開始時と停止時に圧力の振動を生じるのは, こ 
のハンチングが原因であると考えられる.

畑地かんがい地区においては，日常的な補給かんが い水量は比較的小さいが, 気温低下時の霜の害を防止 するために, 防霜用水をスプリンクラーで散布する場合 は, 短時間で多量の栽培管理用水を送水する必要があ り, 両者の流量に大きな違いがある. このように, 低圧化シ ステムを設計流量より小さい流量で運用する場合は, 減圧 弁の継続的なハンチングの発生を避ける必要がある. そ のため, 小口径の減圧弁をバイパス管路として並列に取り 付けて, 小流量においてはバイパス管路に設置した小口 径の減圧弁のみを作動させる対策の導入が有効であると 考えられる.

そこで, 本論文では, 従来型と新型の減圧弁を組み合 わせて並列に設置した低圧化システムを用いて, 通水開 始から停止までの圧力制御機能について検証を行った.

\section{2 主弁とバイパス弁を並列設置した低圧化システム}

低圧化システムの設計においては, 管や減圧弁の口径選 定を行う場合に, 設計流量の決定が重要な要因となる. 設 計流量が大きく, 減圧弁の口径が大きくなる程, 小流量時 における減圧弁の減圧量が大きくなり, 弁体ピストンのスト ロークが小さくなる. そのため, 小流量時には, 減圧弁が 小さい開度で開閉を繰り返すハンチングが発生しやすくな り, 流量変化時の圧力振動の原因となる.

特に, 補給かんがい用水と防霜用水などの栽培管理用 水のように需要量や水利用の時間が大きく異なる2種類の 用水を一つのシステムで切り替えて供給する場合に, 設 計流量より小さい流量で運用する時に, 減圧弁の作動が 不安定になる可能性がある.

この場合には, 減圧弁による圧力制御を安定して行うた めに, 図2に示すように2台の減圧弁を並列して配置し, 主 弁に比較して口径の小さいバイパス用減圧弁を設置する 方法が有効であると考えられる. その場合，バイパス弁か ら主弁に切り替わる流量を確保するために, バイパス用減 圧弁の設定圧力は, 主弁に対して $10 \mathrm{~m}(0.1 \mathrm{MPa})$ 程度高く 設定する必要がある.

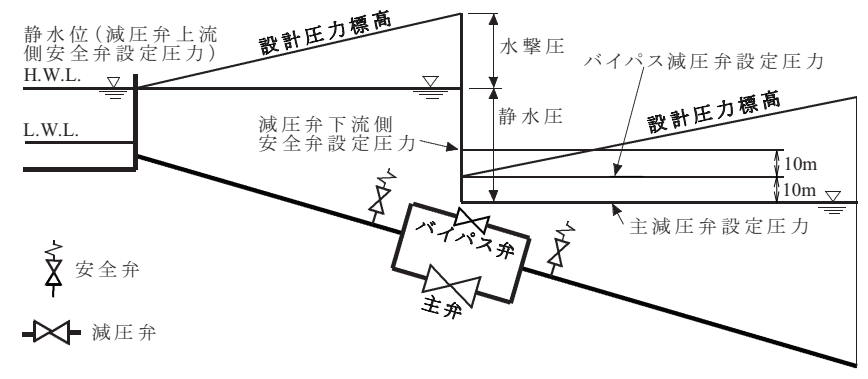

図 2: 減圧弁の並列設置

通水停止から小流量域の段階では, 減圧弁の2次側圧 力は主弁の設定圧力よりも高く, バイパス弁の設定圧力程 度となるため, 主弁は閉鎖している状態で, バイパス弁の みで圧力制御を行うこととなる.

末端での使用流量が増加すると, バイパス弁の開度が 大きくなり, 2次側圧力を一定に保つが, さらに, 使用流量 が増加し, バイパス弁が全開しても設定圧力に制御できな くなると, 減圧弁の2次側圧力は低下し始める.さらに, 使 用流量が増加して, 2次側圧力が主弁の設定圧力よりも低
下すると, 主弁が作動を始め, 主弁の設定圧力で制御を 行うことになる. 一方, 流量が減少する場合は, 主弁, バイ パス弁の順に閉鎖する逆のプロセスをたどる.

\section{3 実験施設}

\section{1 実験パイプライン}

実験に使用した自然流下系パイプラインは, 図3に示すよ うな低圧化パイプラインであり, 始点の加圧機場で加圧ポ ンプを用いて増圧し, 中間地点の減圧弁で減压して末端 の吐水槽まで送水するラインであり, 未端吐水槽の入り口 に末端弁が設置されている. 本実験で使用したポンプ, パ イプライン, 減圧弁および安全弁の諸元を表 1〜 5に示 于.

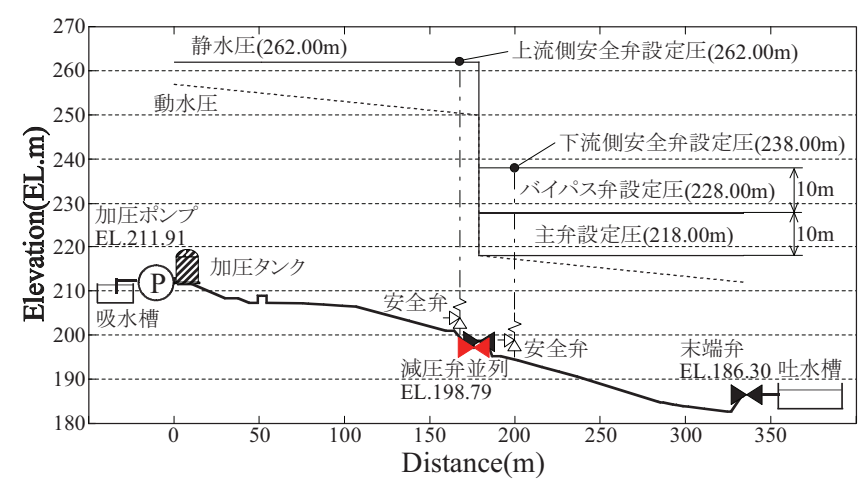

図 3: 実験パイプラインの縦断困

表 1: パイプラインの諸元

\begin{tabular}{lcl} 
口径 & 100 & $\mathrm{~mm}$ \\
延長 & 334 & $\mathrm{~m}$ \\
管種 & $\mathrm{VP}, \mathrm{VH}, \mathrm{SGPW}$ & 混成 \\
管厚 & $6.6,7.6,4.5$ & $\mathrm{~mm}$ \\
吸水槽水位 & 210.80 & EL.m \\
\hline
\end{tabular}

加圧ポンプの出口側には, 加圧タンクが接続されてお り, 加圧タンク内の液面と圧力を一定の範囲に保つため に, 空気の吸排気を行いつつ, ポンプのON-OFF制御を 行う自動運転を行っている.

\begin{tabular}{lcc}
\multicolumn{3}{c}{ 表 2: 加圧ポンプの諸元 } \\
\hline 揚程 & 47 & $\mathrm{~m}$ \\
揚水量 & 0.6 & $\mathrm{~m}^{3} / \mathrm{min}$ \\
台数 & 1 & 台 \\
原動機出力 & 11 & $\mathrm{KW}$ \\
\hline
\end{tabular}

中間地点には減圧弁室が設置されており, 従来型減圧 弁と新型減圧弁が並列に据え付けられている. また, 減圧 弁の上下流には, 安全弁が設置されていて, 実験内容に より安全弁の有無を選択できる.

図3に示す様に, 減圧弁の設定水位は, EL.218.00mと し, 安全弁の設定水位については, 減圧弁上流側は最大 静水位EL. $262.00 \mathrm{~m}$ (本実験ではポンプ締切り圧力)に設 定した。減圧弁下流側安全弁の設定水位は, 減圧弁の締 切時の昇圧分を考慮して, バイパス用減圧弁の2次側設 定水位より $10 \mathrm{~m}$ 高い水位に設定した. 


\begin{tabular}{lll}
\multicolumn{4}{c}{ 表 } & 3: 自動減圧弁の諸元 \\
\hline タイプ & 従来型 $/$ 新型 \\
口径 & 100 & $\mathrm{~mm}$ \\
設置標高 & 198.79 & $\mathrm{EL} . \mathrm{m}$ \\
1次側静水位 & 262.00 & $\mathrm{EL} . \mathrm{m}$ \\
2次側設定水位 & 218.00 & $\mathrm{EL} . \mathrm{m}$ (主弁) \\
2次側設定水位 & 228.00 & EL.m(バイパス弁) \\
\hline
\end{tabular}

安全弁には、弁本体にバネを内蔵した直動式安全弁と パイロット弁を用いたパイロット弁式安全弁があり, 本実験 では，パイロッ卜弁式安全弁(高橋ら，2009a)を使用した。

\begin{tabular}{ccl}
\multicolumn{3}{c}{ 表 } \\
\hline タイプ \\
ロ安全弁の諸元 \\
\hline \multicolumn{3}{c}{ パイロット式 } \\
口径 & 50 & $\mathrm{~mm}$ \\
減圧弁上流側設定水位 & 262.00 & EL.m \\
減圧弁下流側設定水位 & 238.00 & EL.m \\
\hline
\end{tabular}

\begin{tabular}{cll}
\multicolumn{3}{c}{ 表 } \\
5: 末端弁の諸元 & \\
\hline タイプ & 仕切弁 & \\
口径 & 100 & $\mathrm{~mm}$ \\
設置標高 & 186.30 & EL.m \\
\hline
\end{tabular}

\section{2 計測装置}

計測装置の設置状況を図4に示寸. 管路の圧力は圧力卜 ランスミッタ，管路流量は超音波流量計により計測した。安 全弁の吐出流量については, オリフィス前後の差圧を差 圧トランスミッタを用いて計測し，この差圧から換算式(土 木学会，1999）により求めた. 減圧弁のバルブストロークは 変位センサを用いて計測した. 計測されたデータはAD変 換器を通してデジタルデータとして記録した。

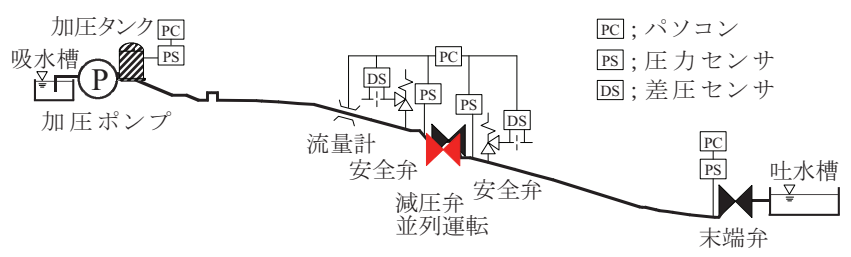

図 4: 計測装置

\section{4. 実験内容と実験方法}

\section{1 実験内容}

本実験は, 作動特性の異なる異機種の従来型減圧弁と新 型減圧弁を並列配置した時の圧力制御機能を確認するこ とが目的である. そこで, 従来型減圧弁と新型減圧弁を主 弁とバイパス弁として割り当て, 両者を切り換え, 減圧弁の 2次側の設定圧力を調整して実験を行った.

同機種の減圧弁を並列に設置した実験を対象としない のは, 以下の理由によるものである.

(1)従来型減圧弁を2台並列に配置する場合

著者らの実験結果 (高橋ら, 2009a) から, 安全弁を併 用しないで減圧弁のみで使用寸ると, 通水停止時に静 水圧が減圧弁の上下流で連続する可能性が高いと考 えられる. 従って, 従来型減圧弁は, 2 次側の圧力制御 を行うために, 常に安全弁の作動を必要とするので, 並 列配置を行うのは, 水撃圧対策の面で適切でないと考
えられる。

(2)新型減圧弁を2台並列に配置する場合

著者らの実験結果 (高橋ら, 2009a) か 吅, 新型減圧弁 のみで2次側圧力制御が可能になるので, 異口径の新 型減圧弁の並列配置は可能であると考えられる. さら に, 水撃圧については, 減圧弁1台設置における対策 （高橋ら, 2009b）を適用することができる.

また，実験設備の制約から同口径の減圧弁を用いたた め, 小口径の減圧弁による微少流量を継続する状態の再 現は行わず, 末端弁を全閉から設定開度まで開き，流量 を安定させてから，全閉まで閉じる操作を行い，流量増減 時の過渡的な状況の再現を対象とした。

実験ケースは表6に示すが，末端弁を操作する場合， 各ケース毎に操作速度を $48 \mathrm{~s}, 24 \mathrm{~s}, 12 \mathrm{~s}$ に変化させて実験を 行った. また, 安全弁がない場合とある場合について実験 を行った。

\begin{tabular}{clcc}
\multicolumn{4}{c}{ 表 6: 実験ケース } \\
\hline ケース & 主弁 & バイパス弁 & 安全弁 \\
\hline A-1 & 従来型 & 新型 & なし \\
A-2 & 新型 & 従来型 & なし \\
B-1 & 従来型 & 新型 & あり \\
B-2 & 新型 & 従来型 & あり \\
\hline
\end{tabular}

\section{2 実験方法}

減圧弁が全閉した静水状態から末端弁を設定した操作速 度で開操作することにより, 減圧弁の2次側圧力を設定圧 より下げて, システムを稼働させた.

流量を $10 \mathrm{~L} / \mathrm{s}$ 程度とし, 未端弁の開度については全閉よ り一回転半開いた位置を全開として設定した。流況が安 定した後, 設定した操作速度で末端弁を全閉まで閉じる 操作を行った. 未端弁の開閉速度は次の3種類について 実験を行った.

(1) $48 \mathrm{~s}$ で全開 $\rightarrow$ 安定後 $\rightarrow 48 \mathrm{~s}$ で全閉

(2) $24 s$ で全開 $\rightarrow$ 安定後 $\rightarrow 24 \mathrm{~s}$ で全閉

(3) $12 \mathrm{~s}$ で全開 $\rightarrow$ 安定後 $\rightarrow 12 \mathrm{~s}$ で全閉

\section{5 実験結果}

図5〜16に各ケースにおける48s，24s，12sの開閉時間で の全閉 $\rightarrow$ 全開 $\rightarrow$ 全閉までの 1 サイクルの圧力, 流量, 弁体 ストロークの変化を示す. 図中のH, QおよびSは以下に示 す管路地点の計測值を示している

なお，パイプライン流量 $\mathrm{Q}_{1}$ は超音波流量計の特性によ り実際の現象より少し遅れ, かつ波形が平滑化されて表示 されている.
$\mathrm{H}_{1}$ : 加圧タンクの圧力標高
$\mathrm{H}_{2}$ : 減圧弁上流側の圧力標高
$\mathrm{H}_{3}$ : 減圧弁下流側の圧力標高
$\mathrm{H}_{4}$ : パイプライン末端の圧力標高
$\mathrm{Q}_{1}$ : パイプライン流量
$\mathrm{Q}_{2}$ : 減圧弁上流側の安全弁吹出流量
$\mathrm{Q}_{3}$ : 減圧弁下流側の安全弁吹出流量
$\mathrm{S}_{1}:$ 新型減圧弁の弁体ストローク
$\mathrm{S}_{2}$ : 従来型減圧の弁体ストローク

5.1 安全弁を使用しない場合（ケースA-1,A-2）

図5〜7はケースA-1の新型減圧弁をバイパス弁として使用 
した場合, 図8～10はケースA-2の従来型減圧弁をバイパ ス弁として使用した場合の全閉 $\rightarrow$ 全開 $\rightarrow$ 全閉までの 1 サイ クルの圧力, 流量, 弁体ストロークの時間変化を示す.

\subsection{1 新型減圧弁をバイパス弁として使用した場合} (ケースA-1)

末端弁を48sで開操作した場合は, 図5に示すように, 管路 の圧力低下に対して, バイパス弁が敏感に反応し, バイパ ス弁が開閉を繰り返し, ハンチングによる圧力脈動の発生 が認められる.また，24s，12sで末端弁を開いた場合は， 図6,7に示すように, 未端弁の操作時間が短いため, バイ パス弁はハンチングがほとんどない状態で開作動するた め, 圧力脈動の発生が少なくなっている.

末端弁を徐々に開いていくと, 流量が増加するため, バイ パス弁による減圧弁下流側の圧力が制御できなくなる.

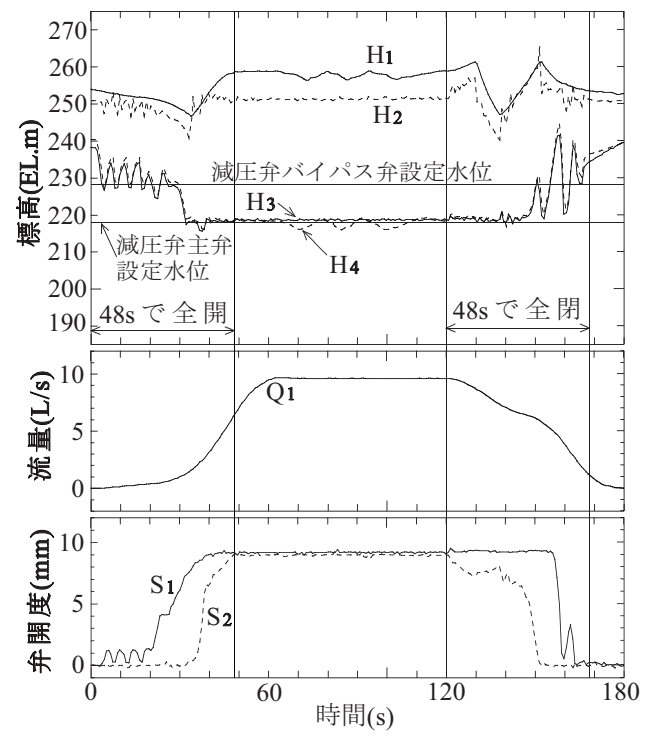

図 5: 減圧弁上下流の圧力・流量変化(A-1，48sで開閉)

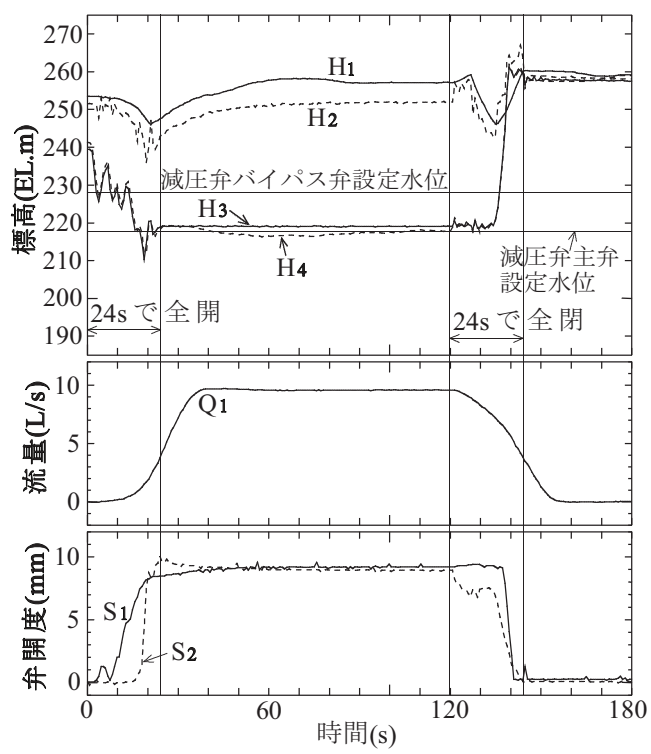

図 6: 減圧弁上下流の圧力・流量変化(A-1，24sで開閉)
その後, 主弁の設定圧力まで減圧弁下流側の圧力が低 下寸ると, 主弁が開き, 減圧弁の下流側圧力が主弁の設 定圧力に制御されるようになる.

末端弁を $48 \mathrm{~s}$ で閉操作する場合は, 管路の圧力が上昇 して, 従来型減圧弁の主弁が先に閉鎖する. 次に, 新型 減圧弁のバイパス弁の設定圧力まで減圧弁下流側の圧 力が上昇すると, バイパス弁が閉鎖し, 減圧并の上流と下 流の圧力を遮断する. しかし，24s，12sで末端弁を閉鎖す る場合は, 主弁の閉鎖が末端弁の操作に対して遅れるた め, 減圧弁の上流側と下流側の圧力が連続する.

末端弁を閉じていくと減圧弁2次側の圧力が高くなるな るが, 主弁の設定圧力を低く設定しているため, バイパス 弁に先行して主弁から先に閉まり始める. 主弁が, 圧力変 化に対して動きが緩やかな従来型減圧弁であるため, 通 水停止時の圧力変動の発生は抑制されている.

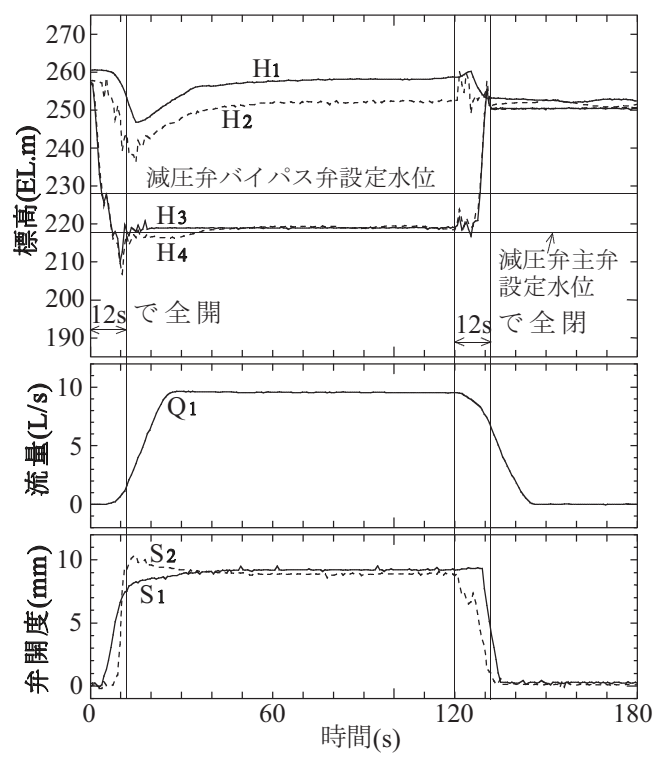

困 7: 減圧弁上下流の圧力・流量変化(A-1, 12sで開閉)

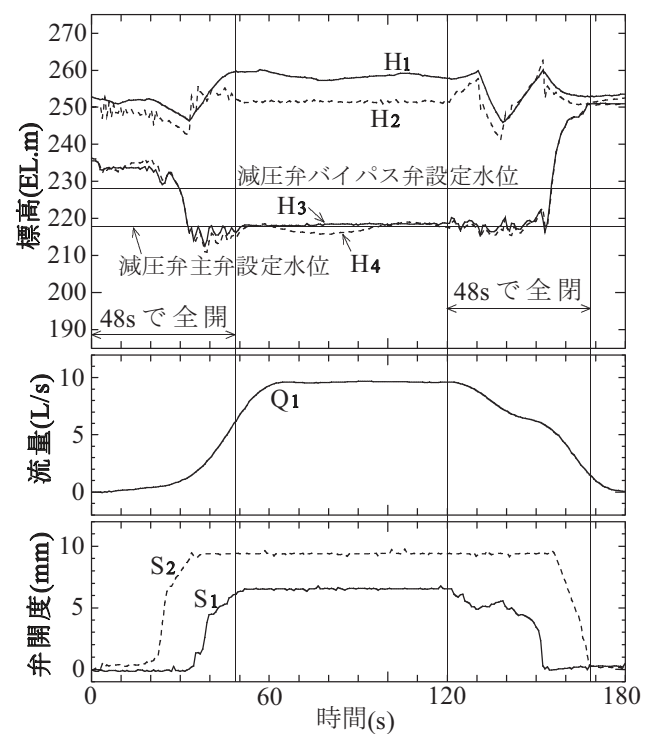

図 8: 減圧弁上下流の圧力・流量変化(A-2, 48sで開閉) 


\subsection{2 従来型減圧弁をバイパス弁として使用した場合 \\ (ケースA-2)}

従来型減圧弁をバイパス弁として使用した場合の圧力と 流量の時間変化を図8～10に示す. 末端弁を全閉状態か ら開いて, 通水を開始する時には, 圧力脈動の発生は認 められない. 通水状態を維持しながら, 末端弁を開操作す ると, 流量が増加して, 管路圧力が低下し, バイパス弁に よる減圧弁下流側の圧力が制御できなくなる.

さらに, 減圧弁下流側の圧力が, 主弁の設定圧力より 低下寸ると, 主弁が開いて減圧弁の下流側圧力を主弁の 設定圧力に制御する.

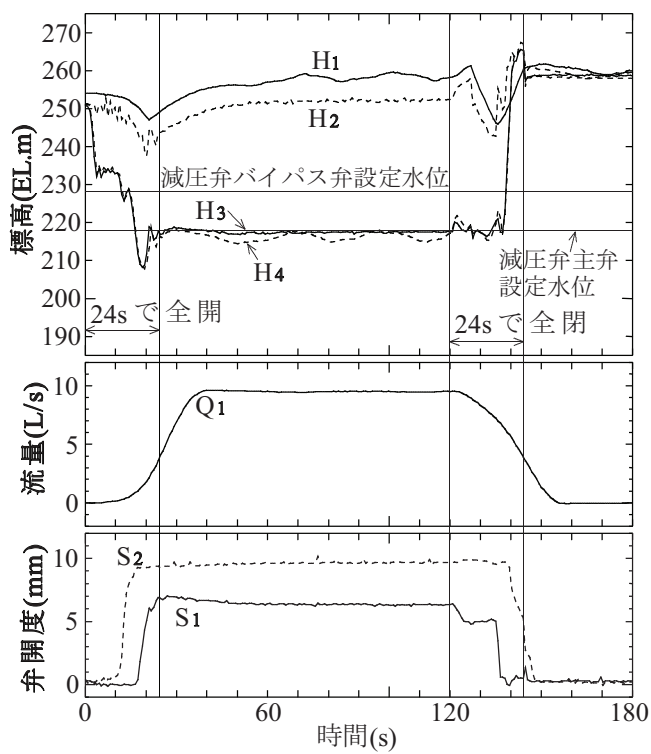

図 9: 減圧弁上下流の圧力・流量変化(A-2, 24sで開閉)

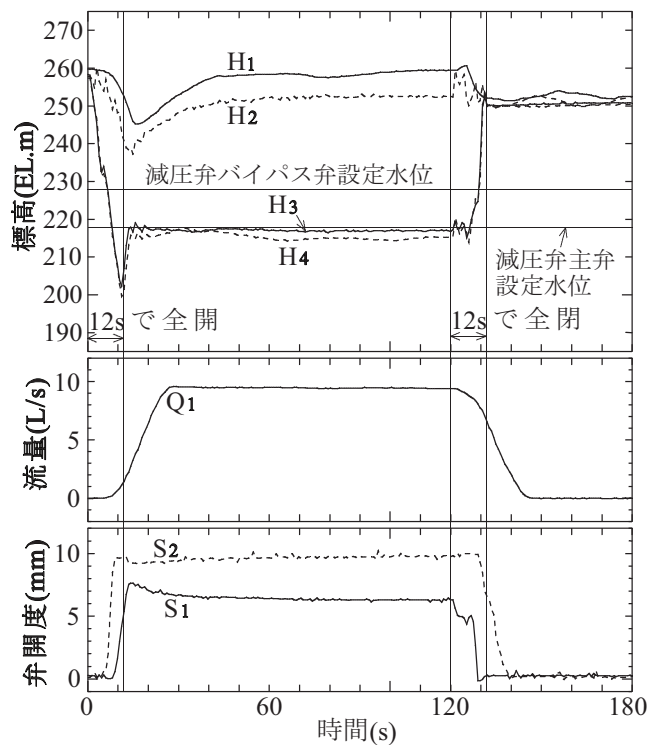

図 10: 減圧弁上下流の圧力・流量変化(A-2，12sで開閉)

末端弁を閉める時には, 新型減圧弁の主弁には閉鎖 遅れは認められないが, 従来型減圧弁をバイパス弁として 用いているため, 従来型減圧弁の閉鎖遅れのために, 本 ケースA-2の全てにおいて, 減圧弁上下流の圧力が連続 した. 従って, 従来型減圧弁をバイパス弁として使用する
方法は, 末端弁の流量変化に対応することが難しいと考 えられる。

\section{2 安全弁を併用した場合（ケースB-1,B-2）}

従来型と新型の減圧弁をそれぞれ主弁とバイパス弁として 組み合わせ, 安全弁を併用した場合の実験結果を検証す る. 図11〜13はケースB-1の新型減圧弁をバイパス弁, 従 来型減圧弁を主弁として使用した場合, 図14～16はケー スB-2の従来型減圧弁をバイパス弁, 新型減圧弁主弁をと して使用した場合の全閉 $\rightarrow$ 全開 $\rightarrow$ 全閉までの1サイクルを 示す.

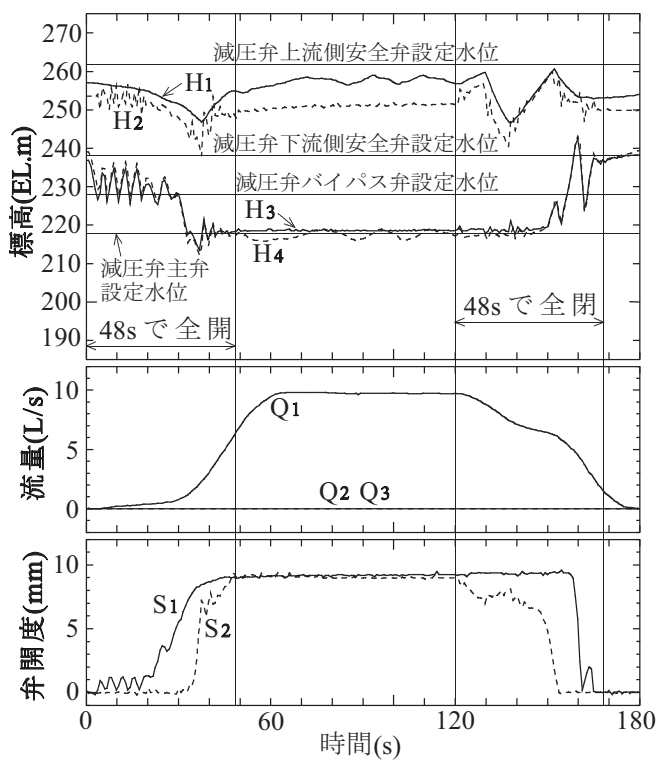

困 11: 減圧弁上下流の圧力・流量変化(B-1，48sで開閉)

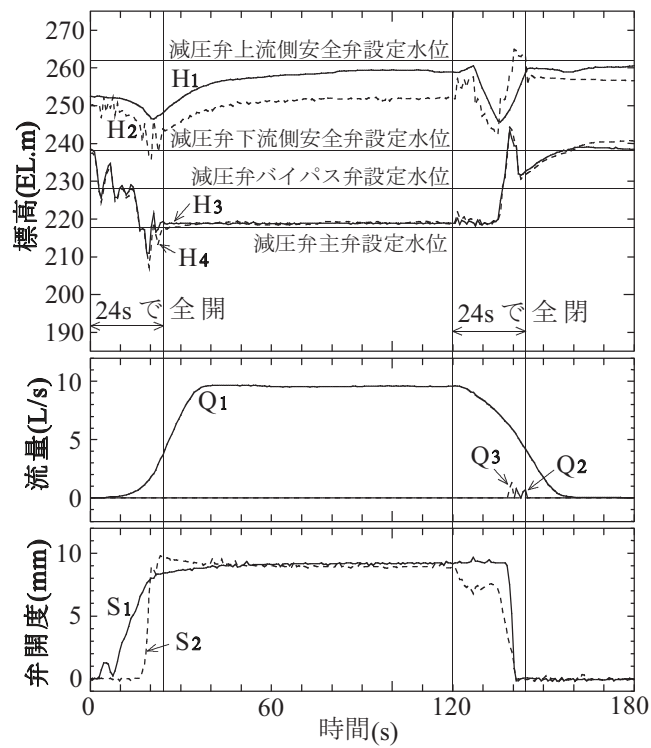

図 12: 減圧弁上下流の圧力・流量変化(B-1，24sで開閉)

\subsection{1 新型減圧弁をバイパス弁として使用した場合 (ケースB-1)}

図11に示すように，末端弁を48sで開く場合は，管路の圧 力が, 安全弁の作動圧力に達していないため, 安全弁の ないケースA-1のときと同様に圧力脈動が発生した.また, 
図12に示すように, 24sで末端弁を閉じる場合は, 減圧弁 上流側と下流側に取り付けられた安全弁が作動して, 流 量 $\mathrm{Q}_{2}, \mathrm{Q}_{3}$ を管内加放出し, 配管内の圧力上昇を抑えて いる. 12sで末端弁を閉じる場合は, 減圧弁の下流側の安 全弁の作動により, 減圧弁下流側の圧力を安全弁の設定 圧力に維持し, 減圧弁上下流の圧力差を確保することが できた。

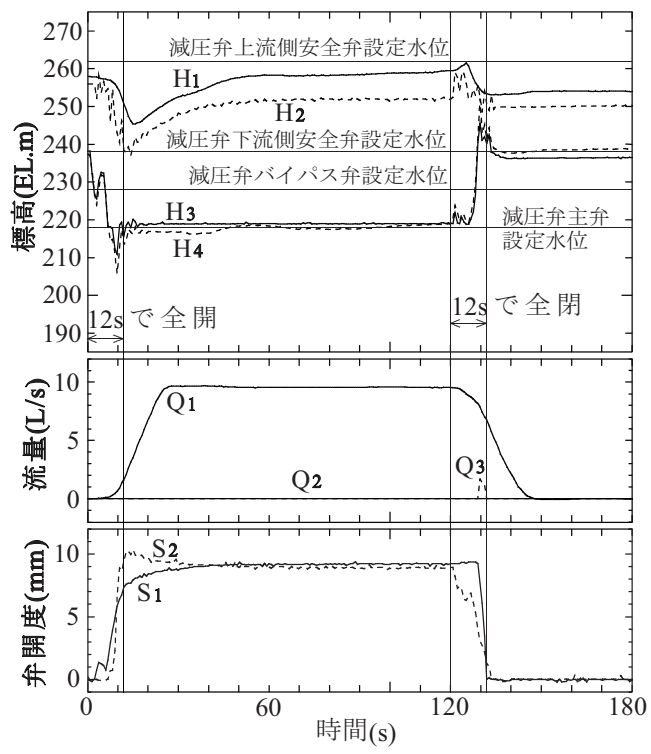

図 13: 減圧弁上下流の圧力・流量変化(B-1，12sで開閉)

\subsection{2 従来型減圧弁をバイパス弁として使用した場合} (ケースB-2)

バイパス弁に従来型減圧弁を用い, 安全弁を併用した場 合の圧力・流量変化の結果を図14～16に示す. バイパス 弁が従来型減圧弁のため, 通水停止時における弁の作 動遅れが発生し, バイパス弁が閉鎖するまで安全弁が管 内圧力を逃がすために放出を続ける. そのため, ケース B-1より安全弁の作動時間が長く, 配管外に逃がす流量は 大きくなる.

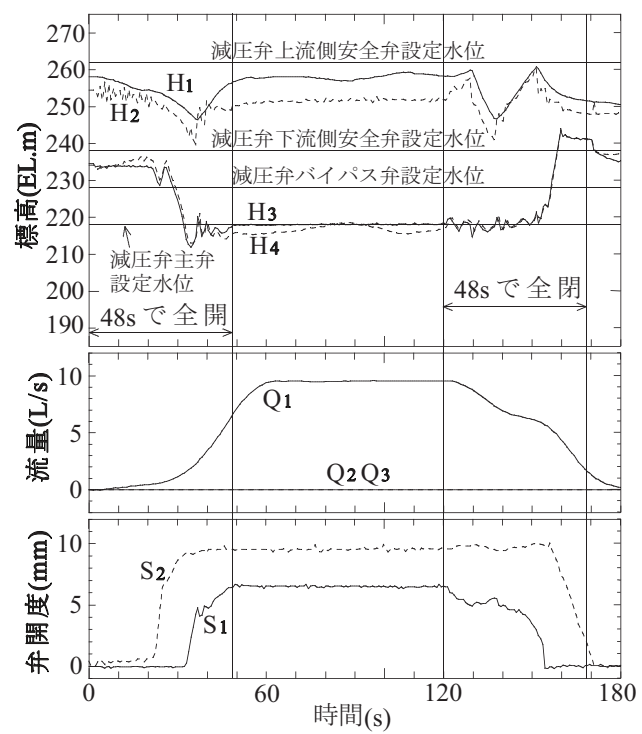

困 14: 減圧弁上下流の圧力・流量変化(B-2, 48sで開閉)

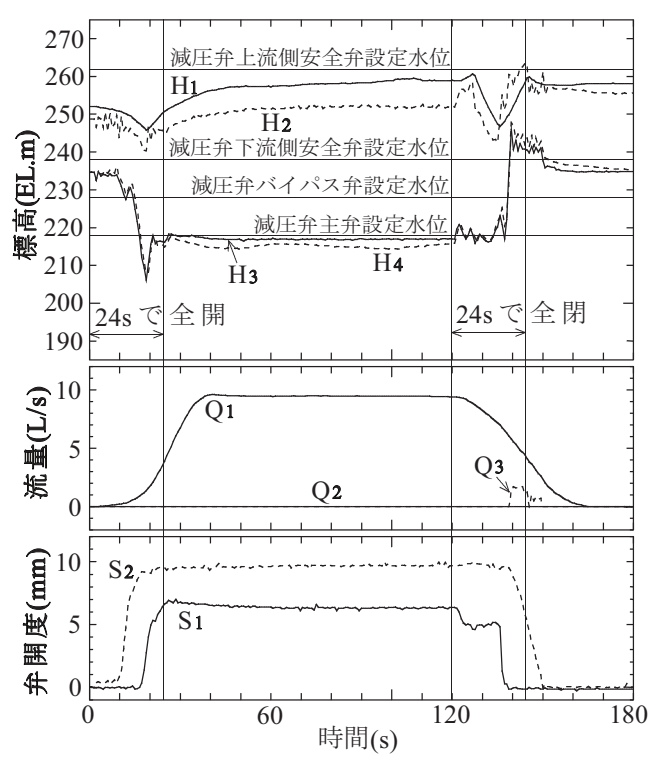

図 15: 減圧弁上下流の圧力・流量変化(B-2, 24sで開閉)

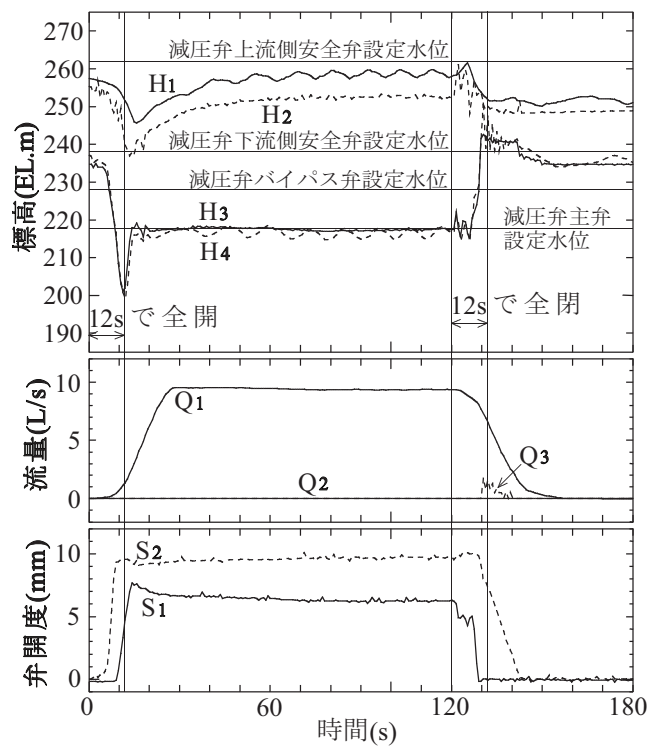

困 16: 減圧弁上下流の圧力・流量変化(B-2, 12sで開閉)

\section{6 末端弁操作時間と制御機能}

\section{1 安全弁の吹出流量}

末端弁操作時間と安全弁からの吹出流量の関係を図 17 に示す.バイパス弁に従来型減圧弁を用いたケースB-2 は，上流側安全弁からの吹出は発生しておらず, 新型減 圧弁を用いたケースB-1に比べて，下流側安全弁からの 吹出流量が大きい. また, バイパス弁に新型減圧弁を用 いたケースB-1の場合は，上流側安全弁からも吹出が発 生している。

安全弁からの吹出流量は, 減圧弁の上流側よりも下流 側からの方が大きくなっており，下流側の安全弁が作動す る原因は, 従来型減圧弁の作動遅れによるものである. ケ 一スB-1において, 上流側安全弁から吹出が発生する原 因は, バイパス弁である新型減圧弁の作動が速いためと 考えられる.

安全弁の吹出流量を，12sと24sで末端弁を閉鎖する場 
合で比較すると, 閉鎖時間の長い $24 \mathrm{~s}$ の方が大きくなる傾 向にある.これは, 24秒で末端弁を閉鎖する場合に, 図 12 と図15に示すように. 末端弁閉鎖と配管内の圧力低下に よるポンプの自動起動が重なったために, 配管内の圧力 が急上昇し，上流側の安全弁が作動したものであると考え られる。

末端弁操作時間と吹出流量の積算值との関係を図 18 に示す. 従来型減圧弁をバイパス弁として用いたケース B-2の下流側安全弁からの積算流出量が大きく, 長時間 の吹出が原因であると考えられる.また，12sと24sで末端 弁を閉鎖する場合で比較すると, 閉鎖時間の長い $24 \mathrm{~s}$ の方 が大きくなる傾向にあり, ポンプの起動が影響していると思 われる。

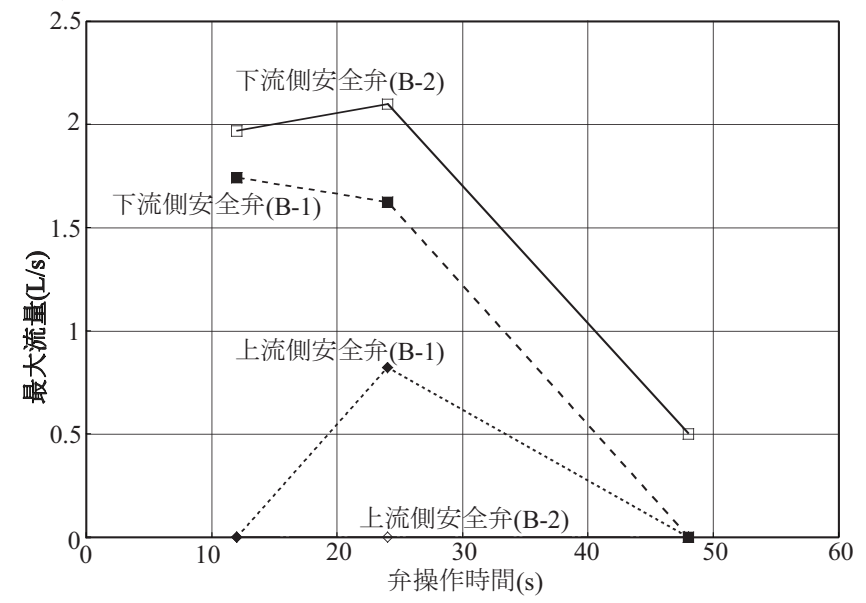

図 17: 末端弁操作時間と安全弁吹出最大流量

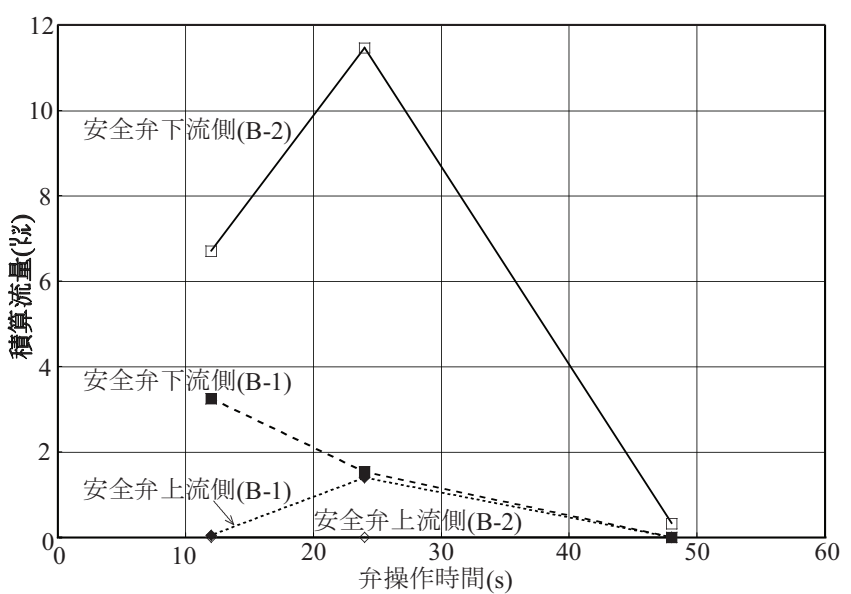

困 18: 末端弁操作時間と安全弁吹出積算流量

\section{2 圧力変動幅}

図 19〜22に末端弁の操作時間と開閉操作にともなう加 圧タンク, 減圧弁上下流, 未端の5地点における圧力変動 幅の関係を示す. 圧力変動幅が小さいほど, 圧力の変動 が小さいため, システムとしては安定しているという判断が できる。

従来型減圧弁をバイパス弁として使用したケースA, B-2 の結果を図20, 図22に示寸が, 新型減圧弁をバイパス弁 として使用したケースA, B-1に比べて, 減圧弁下流側と末 端における圧力変動が大きい. 減圧弁により下流側の圧 力が, 設定圧力に制御されていれば, 変動幅は小さくなる
が, 従来型減圧弁の静水圧の遮断機能が新型減圧弁に 比べて劣るため, 圧力変動が増加している. また, 減圧弁 の上流側については, $30 \mathrm{~m}$ 程度の圧力変動となっている. 加圧タンクは自動運転により起動停止するが, 圧力変動 幅は $15 \mathrm{~m}$ 程度に収まっている。

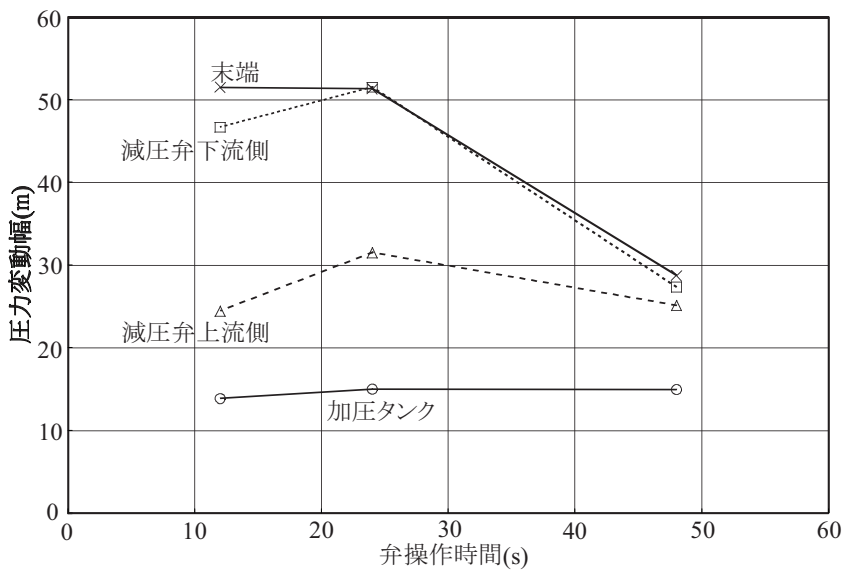

図 19: 末端弁操作時間と圧力変動幅(A-1)

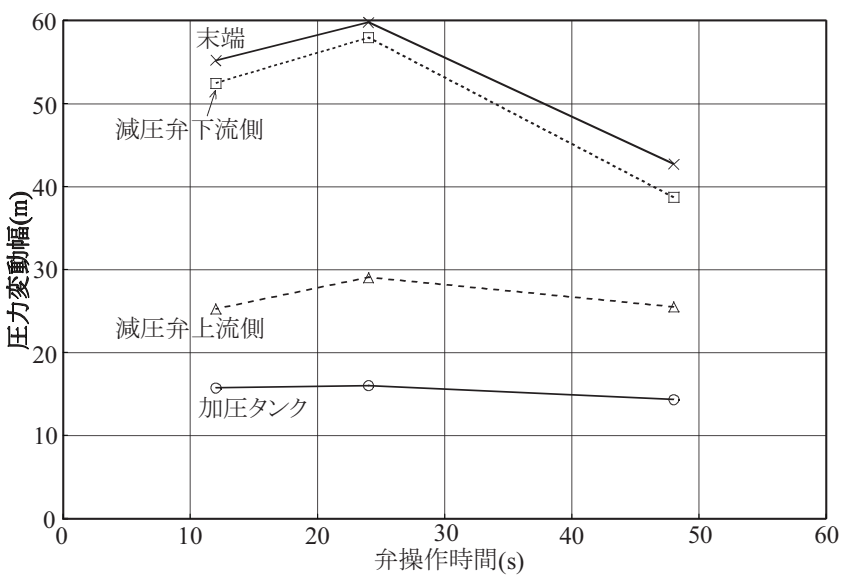

図 20: 末端弁操作時間と圧力変動幅(A-2)

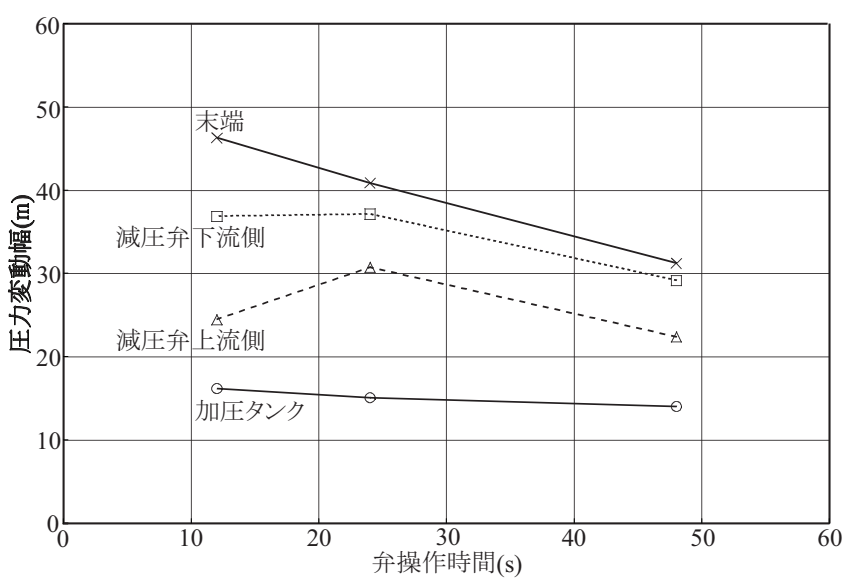

図 21: 末端弁操作時間と圧力変動幅(B-1)

末端弁を開く時間が短い場合には, 流量の供給が追い つかず, 減圧弁下流側の圧力低下が発生しており, また, 末端弁の閉鎖時間が短い場合には, 減圧弁下流側の圧 力が上流側圧力と連続するため, ケースA-2において, 
50mを超える圧力変動となっている.

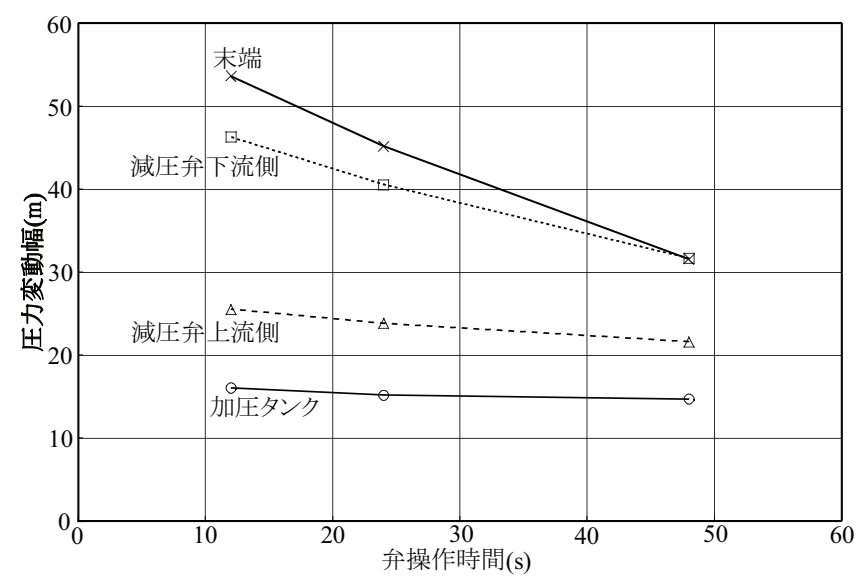

図 22: 末端弁操作時間と圧力変動幅(B-2)

\section{7 おわりに}

本実験においては, 従来型と新型の減圧弁を並列に設置 した場合の圧力制御機能についての検証を行った. 検証 により得られた結果を以下に整理して示寸.

(1)従来型と新型の減圧弁を組み合わせて並列配置し, 安 全弁を併用しない場合は, 従来型減圧弁の特性が優先さ れるため, 通水停止時に静水圧が減圧弁の上下流で連 続する現象を生じる.

(2)減圧弁を直列配置する場合には, 従来型と新型の組み 合わせは可能であるが, 主弁とバイパス弁として並列に設 置する場合は, 減圧弁の 2 次側圧力を制御するために, 安 全弁を常に併用する対策が必要となる.

(3)従来型減圧弁は通水停止や微少流量時での圧力制御 機能が新型減圧弁に対して劣るため, 未端弁の流量変化 に対応寸るのが難しい. そのため, 新型減圧弁を主弁, 従 来型減圧弁をバイパス弁として組み合わせると, システム 全体の圧力変動が大きくなる.

(4)従来型減圧弁は新型減圧弁に比較して動きが緩やか なことから, 従来型減圧弁を主弁, 新型減圧弁をバイパス 弁として組み合わせれば, 減圧弁の2次側圧力の制御を 安全弁に依存寸ることなく, 流量の変化に対応した圧力制 御が可能となる.

これまでの一連の実験により，低圧化システムにおける 減圧弁と安全弁についての使用方法について概ねのガイ
ドラインを整備できる知見が得られたと考えている. 今後の 課題としては, 低圧化システムに定流量弁を組み込んだ 場合における安定性について, 現地試験による検討を加 え，報告する．

\section{謝辞}

本研究は, 平成19,20年度日本学術振興会科学研究費 補助金(基盤研究(C)課題番号19580282)ならびに九州農 政局計画基礎諸元調查解析 (用水・畑) 南九州地区委託 事業の助成を受けた. また, 現地実験では, 南薩土地改 良区の樋渡実広氏, 俵積田秀人氏, 寺田功次氏の協力 を得た.ここに記して謝意を表する。

\section{引用文献}

[1] 土木学会 (1999): 水理公式集 [平成 11年版], pp.383-384.

[2] 稲垣仁根 - 國武昌人 (1996): 新型自動減圧弁による管 路圧力の制御技術, 農業土木学会誌, 64(3), pp.57-62.

[3] 稲垣仁根 - 小路順一 - 近藤文義 (1998): 新型自動減圧 弁を直列配置した低圧化パイプラインシステムのシミュレ ーション, 農業土木学会論文集, 196, pp.27-39.

[4] 稲垣仁根 - 小倉邦雄 - 角田範明 - 近藤文義 (1999): 安 全弁による低圧化パイプラインシステムの水撃圧対策, 農業土木学論文集, 200, pp.93-103.

[5] 斎藤正樹・稲垣仁根 (1996): 自動減圧弁によるパイプラ インの低圧化システムと現地計測, 農業土木学会論文集, 183, pp.129-141.

[6] 斎藤正樹・稲垣仁根 (1997): 自動減圧弁によるパイプラ インの実測とシミュレーション, 農業土木学会論文集, 187, pp.111-122.

[7] 高橋研二 ·稲垣仁根 - 多炭雅博 - 竹下伸一 (2009a): 安全弁による低圧化システムの圧力制御対策 (I) - 自 動減圧弁を単独設置した場合 -, 雨水資源化システム 学会誌, 15(1), pp.23-30.

[8] 高橋研二 ·稲垣仁根 - 多炭雅博 - 竹下伸一 (2009b): 安全弁による低圧化システムの圧力制御対策（II）安全弁による水撃圧対策 -, 雨水資源化システム学会 誌, 15(1), pp.31-40.

[9] 高橋研二 ・稲垣仁根 - 多炭雅博 - 竹下伸一 (2010): 安 全弁による低圧化システムの圧力制御対策（III）- 自 動減圧弁を直列設置した場合 - , 雨水資源化システム 学会誌, 15(2), pp.73-84.

この論文の公開の質疑または討議は2011年6月30日 まで受付けます。 